\title{
The characteristics of private forest management in Wonogiri District, Central Java, Indonesia and it's contribution to farm household income and village economy
}

\author{
Iin IchWANDI,*, Takeo ShINOHARA ${ }^{2}$ and Yuei NAKAMA ${ }^{2}$ \\ Faculty of Forestry, Bogor Agricultural University, Kampus IPB Darmaga PO Box 168 Bogor-16001, Bogor, Indonesia \\ ${ }^{2}$ Faculty of Agriculture, University of the Ryukyus, Okinawa 903-0213, Japan \\ * Corresponding author: Iin ICHWANDI, E-mail: iichwandi@yahoo.com, Tel/Fax: +62-251-623805, 621677
}

\begin{abstract}
This study observes the characteristics of private forest (PF) in Sumberejo village and the role played by $P F$ on farm household and village economy. Economic base techniques including location quotient (LQ), surplus of income, and multiplier effect $\left(\mathrm{M}_{\mathrm{e}}\right)$ were applied. PF in Sumberejo were developed by farmers with timber trees species, mainly teak and mahogany which were planted on three forms of the silvicultural system, i.e. monoculture, polyculture, and agroforestry. The farmers managed PF on their own habit to determine such constraints concerning their land and to respond a high demand of timber in Java. Many buyers involved in timber market in Sumberejo created a variety of marketing channels which give farmers to choice the convenience's buyers. Even though, PF has not contributed a big portion to the total household income, but it was important as saving asset. Economic base analysis confirmed that $\mathrm{PF}$ is a basic sector of the economy in Sumberejo and created surplus of income for that village. Further analysis proved that $P F$ has the biggest $M_{e}$ value. This indicated that $P F$ is "prime mover role" sector and therefore it can be promoted as "engine" for economic development of that village.
\end{abstract}

Key words: private forest, household income, basic sector, village economy, Wonogiri.

\section{INTRODUCTION}

Many researchers reported that many farmers in various parts of rural Java planted trees on their own land which

This paper was presented on oral presentation on symposium conducted by Kyushu Branch of the Japanese Forestry Society, Kagoshima in October 2004
Indonesian call it as hutan rakyat or private forest (PF). Other terms of PF used by many researchers are tree farming, farm forestry, or farm-tree planting, which indicates the management of trees by individual in the form of woodlots or agroforestry on private or customary land (Robert and Dubois, 1996; Nemoto, 2002). In a broad sense, the term of PF includes home gardens and other tree-oriented land uses on agroforestry system (Wiersum, 1982; Nair, 1993; Simon, 1999). PF were developed mostly in dry land or upland area. They were scattered on the island of Java from the Banten to the East Java Province. $\mathrm{PF}$ were more dominated in the centre and southern parts of the island, which is mostly dry and mountainous (Ichwandi et al. 2005). According to establishment's funding-sources, Ministry of Forestry (2003) estimated about 400.5 thousand ha of the PF around Java consist of different types (Table 1). Based on this data, most of the $\mathrm{PF}$ were established in Central Java Province by farmers and afforestation programs.

In the early 1970s, the Indonesia government initiated large-scale afforestation programs in many villages in Java. To create a mass drive, strong incentives were given to the farmers such as giving seedling subsidies and training farmers for planting tress or in making terraces on their land. These programs were carried out by local government in district level via the Dinas Perhutanan dan Konservasi Tanah (Forest and Land Conservation Agency). In 1984, the Forestry Department expanded the afforestation program by promoting PF with activities such as subsidizing seeds, making demonstration plots, constructing village's nurseries (kebun bibit desa) for PF, and training forestfarmers groups. By introducing the Ministry of Forestry Decree No. 54/Kpts-II/1997, government provided credit's subsidy to expand the PF as a forestry-business unit in the village. The Indonesian government decided those policy and programs with expectation that PF could become an alternative to minimize land degradation, to 
Table 1. The PF in Java classified by the funding source.

\begin{tabular}{lrrrrrr}
\hline \multirow{2}{*}{$\begin{array}{c}\text { The PF depending } \\
\text { fund source }\end{array}$} & $\begin{array}{c}\text { Province (ha) } \\
\text { West Java } \\
\text { + Banten }\end{array}$ & $\begin{array}{c}\text { Central } \\
\text { Java }\end{array}$ & $\begin{array}{c}\text { East } \\
\text { Java }\end{array}$ & Jogyakarta & $\begin{array}{c}\text { Total } \\
\text { (ha) }\end{array}$ \\
\hline Self supporting \& Afforestation & 44,984 & 180,244 & 69,780 & 25,739 & 320,747 \\
The PF credit scheme (KUHR) & 18,672 & 4,796 & 7,005 & - & 30,474 \\
Demonstration plots model & 4,400 & 3,850 & 5,225 & 825 & 14,300 \\
Economic crisis program & 11,000 & 9,900 & 11,550 & 2,475 & 34,925 \\
\hline Total PF Area (ha) & 79,056 & 198,790 & 93,561 & 29,039 & 400,446 \\
\hline
\end{tabular}

Source: Forestry Department, 2002

Note: Plants species are albizia, teak, mahogany, sonokeling (Dalbergia latifolia), suren (Toona sinensis), mindi (Melia azedarach), and others.

reduce the shortage of timber supply, and to encourage the economic development in rural Java. According to Anonymous (1996), wood consumption in Java was around 16 million cubic meters among which more than half were supplied from the PF. Other research conducted by Soerjohadikoesumo (1980) indicated that the PF supplied approximately $66 \%$ of timber needs in Java.

Recent study of PF in rural Java conducted by Ichwandi et al. (2005) found some characteristics of the $\mathrm{PF}$ management applied by farmers, the PF contribution to farmer's household income, and the prospective of $\mathrm{PF}$ as farm-business investment in rural Java. This study concluded that PF has not contributed a big portion to the total household income, but it was important as saving asset. Using financial analysis, the study also proved that PF, especially for growing albizia (Paraserianthes falcataria), has a high return of investment, and then it can be promoted as farm-business investment in rural Java. In spite of that, the remaining issue brought forward is how the PF contribute to rural economy and whether it can be promoted for local economic development. To answer these questions, further study is needed.

Research concerning local economy is usually conducted via analysis using a variety of economic base analytical techniques. Klosterman (1990) noted that economic base technique is the oldest, simple, and most widely used technique for regional economic analysis. The economic base technique is grounded in the assumption that the local economy can be divided into two very general sectors, i.e. a basic sector and a non-basic sector. The basic sector is the prime cause of local economic growth and therefore is identified as the "engine" of the local economy. Based on above-point of view, the objective of this study is focused to investigate the role played by PF on village economy. Study was conducted on location where the PF has been applied by farmers on large area with a consideration that PF has significant impact on rural economy. Based on that reason and availability of data, Sumberejo Village in Wonogiri District, Central Java was chosen. To provide broad view concerning characteristics of $\mathrm{PF}$ in Java, this study also evaluated the PF management applied by farmers and its contribution to farmer's household income.

\section{STUDY SITE AND METHODS}

Wonogiri in Central Java Province has long been known for its dry, barren areas that recurrently experience clean water shortages during the dry season. Wonogiri has an area of 182,236 ha. Elevations are generally between 100 and 600 meters with mean annual temperatures ranging from $24^{\circ}$ to $32^{\circ} \mathrm{C}$. Annual rainfall is about 1,900 $\mathrm{mm}$ with higher intensities between October and June. July through September is the dry season with rainfall generally below $50 \mathrm{~cm} /$ month. Upland soils are lithosols of limestone origins, well drained and depleted of nutrients. Lowland soils of volcanic origins, support productive irrigated rice systems that yield three crops per year. Upland cropping systems (corn, upland rice or cassava) are less productive and profitable due to inherently infertile soils and reliance on rainfall. As agricultural yields declined, forest cover including PF, community forest, and state forest are developed. A summary of land use in Wonogiri is presented in Table 2. Wonogiri District consists of 14 sub-districts, one of which is Batuwarno Sub-district (Wonogiri District Statistic

Table 2. Land use in Wonogiri District.

\begin{tabular}{lrc}
\hline \multicolumn{1}{c}{ Land use } & Area (ha) & Percentage (\%) \\
\hline Rice field & 30,701 & 16.85 \\
Dry land farming & 61,011 & 33.48 \\
Home garden & 36,026 & 19.77 \\
Community forest & 12,879 & 7.07 \\
State forest & 16,268 & 8.93 \\
Other & 25,351 & 13.91 \\
\hline Total land area & 182,236 & 100.00 \\
\hline
\end{tabular}

Source: Wonogiri District Statistic Office, 2000 


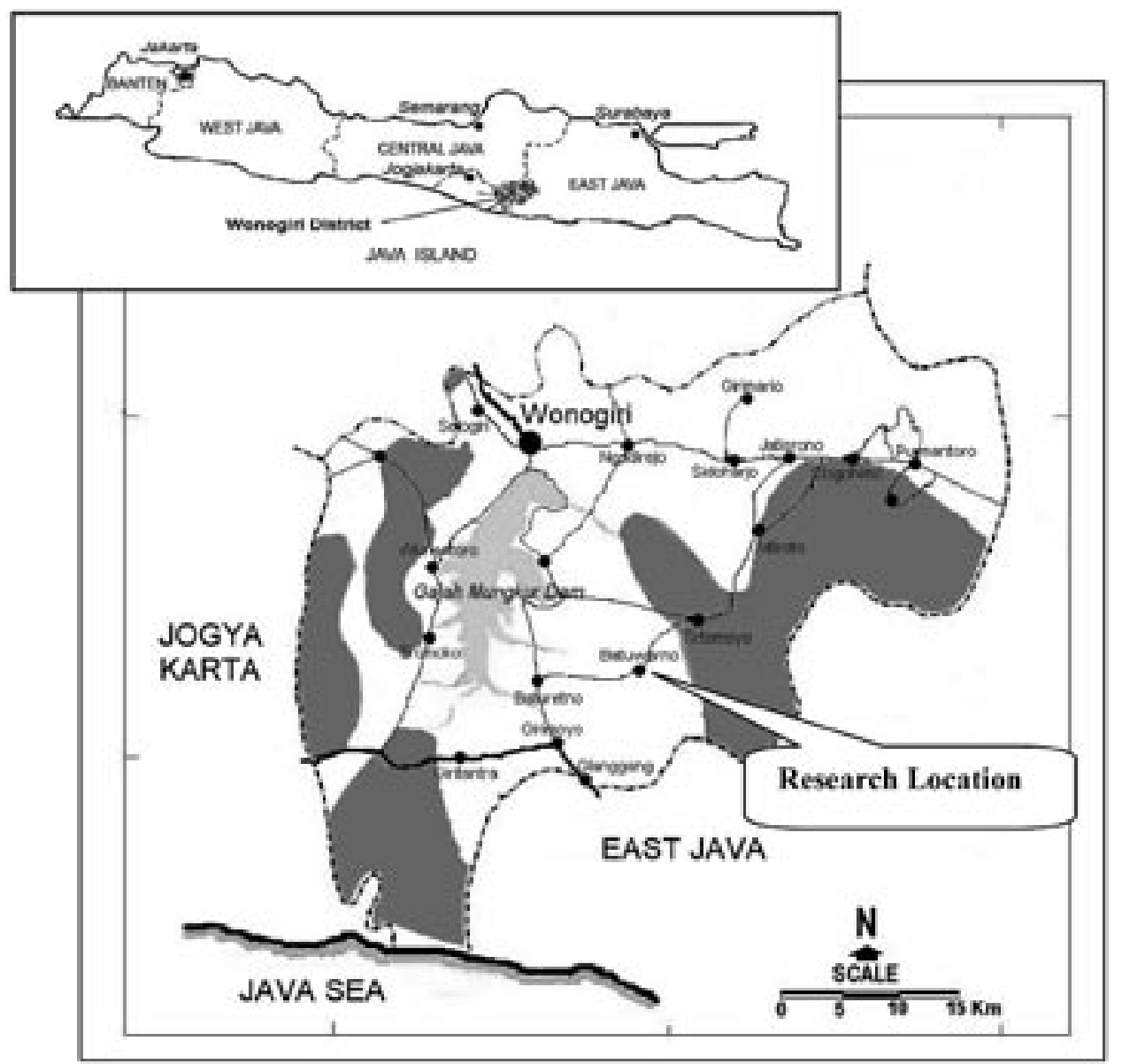

Fig. 1. Map of study site

of $10 \mathrm{~m} \times 20 \mathrm{~m}(0.02$ ha/plot). The data were analyzed descriptively to provide information on the development and management characteristics of $P F$ in the village. Quantitative analysis was conducted to obtain information concerning the farmer' s household income from $\mathrm{PF}$ and others sources, growing stock (trees/ha) and stands structure pattern of PF. To estimate the role of $\mathrm{PF}$ in village economy, the concept of economic base including a location quotient (LQ), surplus of income $\left(\mathrm{S}_{\mathrm{y}}\right)$ and multiplier effect $\left(\mathrm{M}_{\mathrm{e}}\right)$ analysis were applied. To support these analyses, secondary data concerning village and regional income

Office, 2000).

This study was conducted in Sumberejo Village in Batuwarno Sub-district in 2000. This village has been chosen with a consideration that PF is well developed in a large area and many farmers in this village are known to succeed in managing PF by themselves. The area size of this village is 547 ha which situates $46.5 \mathrm{~km}$ from the capital of Wonogiri District (see Fig. 1). The geographical characteristic of the village is mainly hilly and dominated by limestone parent rocks. Land use is dominated by dry land farming which amounts to 415.72 ha (76\%). Others include home gardens, paddy fields, and residences. The number of inhabitants of Sumberejo Village was 2,215 with population density of 405 people per $\mathrm{km}^{2}$ (Wonogiri District Statistic Office, 2000).

To observe the PF management practiced by farmers in establishing PF, field research was conducted by interviewing 60 farmers in the village as respondents. The respondents were selected on base of PF land ownership level, e.g. level I (< $1 \mathrm{ha})$, level II (1-2 ha), and level III (> 2 ha). To estimate growing stock of PF, forest inventory was made on 25 sample plots which each plot has size were obtained from village, sub-district offices, and Wonogiri District Statistics Office.

The LQ technique is most commonly utilized in economic base analysis method. This technique compares the local economy (village) to a large geographic unit (sub-district), in the process attempting to identify specializations in the local economy. The LQ technique is based on the calculated ratio between the local economy and an economy of same reference unit (Hoover, 1971; Isard, 1972; Isserman, 1977). To determine whether the $\mathrm{PF}$ in the village could be categorized as a basic or a nonbasic sector, the LQ technique was applied using the following equation.

$$
L Q_{x}=y_{x i} / y_{t}: Y_{x j} / Y_{j}
$$

Where:

$y_{x i}=$ Income from sector $\mathrm{x}$ (the PF) in region i (Sumberejo Village) in year $\mathrm{t}$

$y_{t}=$ Income from all sectors in region i (Sumberejo Village) in year $\mathrm{t}$

$Y_{x j}=$ Income from sector $\mathrm{x}$ (the $\mathrm{PF}$ ) in a larger region $\mathrm{j}$ (Batuwarno Sub-district) in year $\mathrm{t}$

$Y_{j}=$ Income from all sectors in region $\mathrm{j}$ (Batuwarno Sub- 
district) in year $\mathrm{t}$

A certain sector is categorized as a basic sector when $\mathrm{LQ}$ value $>1$, and as a non-basic sector when $\mathrm{LQ}$ value $<$ 1. The basic sector which has LQ value more than one means that this sector produce more than what a local economy should have to serve local needs and its surplus was exported beyond its borders and bringing money to the local community. To calculate surplus of income produced by $\mathrm{PF}$ sector in village, the following equation was applied;

$$
S_{y i}=\left[\left(y_{x i} / y_{t i}\right)-\left(Y_{x j} / Y_{t i}\right)\right] x Y_{x i}
$$

Where:

$S_{y i}=$ Surplus of income in region i (Sumberejo Village)

$y_{x i}=$ Income from sector $\mathrm{x}$ (the PF) in region i (Sumberejo Village)

$Y_{x j}=$ Income from sector $\mathrm{x}$ (the $\mathrm{PF}$ ) in region $\mathrm{j}$ (Batuwarno Sub-district)

$y_{t i}=$ Total income from all sectors in region i (Sumberejo Village)

$Y_{t j}=$ Total income from all sectors in region $\mathrm{j}$ (Batuwarno Sub-district)

To determine how a certain basic sector affects a non-basic sector in the village, the coefficient of multiplier effect $\left(M_{e}\right)$ has to be used. The term "multiplier effect" is used to describe the full effect of basic sector to economic activity on a local community. It refers to the notion that money (income) received by basic sector is at least partially spent in the community on the purchase of goods and services which then supports other nonbasic sectors. The $\mathrm{M}_{\mathrm{e}}$ was calculated using the following equation;

$$
\begin{aligned}
& \qquad M_{e}=Y / Y_{b} \\
& \text { Where: } \\
& Y=\text { Total income from all sectors } \\
& Y_{b}=\text { Income from a basic sector }
\end{aligned}
$$

\section{RESULTS}

\section{Management of the PF in Sumberejo}

Based on the eldest people in the Sumberejo, the PF in this village were established by the farmers since 1967 . They found that their existing land deteriorated and food crops could not be well planted and considered that planting the lands with timber crops gave a better chance to support their livelihood. For this reason, the farmers planted their own land with teak (Tectona grandis) and mahogany (Swietenia macrophylla), which were easy to tend and have high demand and price. Besides the selfsupporting planting activities, the farmers also gained subsidies from the afforestation project under World Food Program (WFP) in 1973, and the government in 1976/1977 and 1994/1995.

Based on our survey, most farmers have land less than one hectare. Consequently, about $78 \%$ of farmers in Sumberejo have a small area of PF with average 0.65 ha per household. It is not surprising because the average land ownership in Java is also small. The average area of land owned by farmers in rural area of Java was only about 0.5 ha per household (BPS, 1993). In managing the $\mathrm{PF}$, farmers in Sumberejo planted many trees species, but there are two species which were preferred: teak and mahogany. These species are chosen by farmers because a high demand for those timbers in Java. PF in Sumberejo are planted by farmers in three forms of silvicultural system, including monoculture, polyculture, and agroforestry. Polyculture means that PF are developed the same as monoculture but with more than one species. Most of farmers developed PF on agroforestry system. In our survey, about $67 \%$ of farmers choose this system. In this system, farmers still have chance to plant agriculture crops on the open area of trees spacing. However, when farmer did not plant agriculture crops because of stony land or high elevation, farmers developed the PF on the form of monoculture or polyculture. This system is also applied by farmers who have wider land but limited household-labors. The planting is initially conducted with spacing of $3 \mathrm{~m} \times 3 \mathrm{~m}$ or $5 \mathrm{~m} \times 5 \mathrm{~m}$. Because of the land stoniness, the predetermined spacing is not much considered. This way spacing results in the irregular shape of the tree stands. Replanting is conducted at the beginning of planting activity with the aim to replace dead or suppressed plants. Farmers obtained planting materials of teak and mahogany from various sources such as stump (coppice system), seedling from natural regeneration or bought from seedling sellers in a local market, and sometimes got seedling from government subsidies. In spite of that, about $65 \%$ of farmers used natural seedling. Stand maintenance was conducted by weeding and pruning. To protect from land sliding and erosion, the farmers constructed permanent stone terraces, because the PF land is situated in the area with considerable steepness (the slope are around 30\% - 45\%). However, there are no other tending activities such as fertilizing, thinning, or pest and disease control carried out by the farmers. Based on our survey, the characteristics of PF management conducted by farmers is summarized in Table 3.

The farmers have to select mature trees to harvest or sell those trees whose estimated diameter of the tree 
Table 3. Characteristics of forest management in Sumberejo.

\begin{tabular}{|c|c|c|c|c|c|c|c|}
\hline No. & $\begin{array}{c}\text { Forest } \\
\text { management }\end{array}$ & $\begin{array}{l}\text { Number } \\
\text { of farmer }\end{array}$ & $(\%)$ & No. & $\begin{array}{c}\text { Forest } \\
\text { management }\end{array}$ & $\begin{array}{l}\text { Number } \\
\text { of farmer }\end{array}$ & $(\%)$ \\
\hline A. & Land and PF ownership & & & & & & \\
\hline \multirow[t]{4}{*}{1.} & Land ownership: & & & 2. & PF ownership: & & \\
\hline & a. $<1$ ha & 44 & $(73)$ & & a. $<1$ ha & 47 & (78) \\
\hline & b. $1-2$ ha & 11 & (18) & & b. $1-2$ ha & 9 & (15) \\
\hline & c. $>2$ ha & 5 & (9) & & c. $>2$ ha & 4 & $(7)$ \\
\hline B. & Silvicultural system & & & & & & \\
\hline \multirow[t]{4}{*}{1.} & Planting system: & & & 3. & Spacing of planting: & & \\
\hline & a. Monoculture & 11 & (18) & & a. Regular & 13 & (22) \\
\hline & b. Polyculture & 9 & (15) & & b. Irregular & 47 & (78) \\
\hline & c. Agroforestry & 40 & (67) & 4. & Forest maintaining: & & \\
\hline \multirow[t]{4}{*}{2.} & Planting material: & & & & a. Just Weeding & 17 & (29) \\
\hline & a. Natural seedling & 39 & $(65)$ & & b. Weeding \& Pruning & 41 & (68) \\
\hline & b. Buying seedling & 9 & (15) & & c. No maintenance & 2 & ( 3$)$ \\
\hline & c. Coppice system & 12 & $(20)$ & & & & \\
\hline \multirow{4}{*}{$\begin{array}{l}\text { C. } \\
1 .\end{array}$} & Harvesting and marketing system & & & & & & \\
\hline & Type of harvesting: & & & & & & \\
\hline & a. Clear felling & 7 & $(12)$ & 3. & Sold to whom? & & \\
\hline & b. Selective felling & 53 & $(88)$ & & a. Assemblers & 38 & (64) \\
\hline \multirow[t]{3}{*}{2.} & Form of selling: & & & & b. Wholesalers & 14 & (23) \\
\hline & a. Timber trees & 52 & $(87)$ & & c. Wood processors & 8 & (13) \\
\hline & b. Timber logs & 8 & (13) & & & & \\
\hline
\end{tabular}

Source: Field survey in 2000. Research was conducted by interviewing 60 farmers. Trees planted comprises mainly teak and mahogany species

stand reaches around $30 \mathrm{~cm}$. However, under certain condition when farmers need cash, timber trees were harvested even if they were not mature yet. After harvesting, they usually do not plant the logged over areas, because new plants grow from natural regeneration or by coppice system. Therefore, they do not really need to provide artificial planting stocks anymore. Most farmers in Sumberejo sold the timber to the buyers when it is still a standing tree (stumpage). Buyers who consist of assemblers (timber middleman), wholesalers, and wood processors (commonly saw-millers) usually visit the sites to conduct transactions. After a deal has been made, the buyers would do harvesting because they have more proper facilities and equipments such as chainsaw and transporting vehicles.

\section{Growing stock of PF}

The fact that the farmers harvest or sell timber trees selectively when they were mature enough or during the emergency situation resulted in different stand structure pattern and variety of growing stock (trees/ha). Based on tree stands inventory on sampling plots the growing stock of PF in Sumberejo differs between monoculture and agroforestry planting system. Number of stands per hectare in monoculture was twice bigger than agroforestry. As presented in Table 4, the stand density of PF in Sumberejo with diameter class of more than 5 $\mathrm{cm}$ on monoculture and agroforestry planting system are about 1,990 trees/ha and 940 trees/ha, respectively. Since the area size of the PF in the Sumberejo is 131.13 ha, therefore we estimated that the total of growing stock in this village range from 123,000 to 260,000 trees.

\section{Contribution of the PF to farmer's household income}

Due to unreliable data on serial years, farmer's household income was only observed from a year before the year of the research. Based on the observations, the income sources of the farmer's household were various. They consist of PF, agricultural crops (rice and dry-land farming), livestock, and other sources (Table 5). In one year, the most income was gained from agricultural crops. The agricultural crops totally contributed $36.62 \%$ (rice farming was $10.61 \%$ and dry-land farming was $26.01 \%$ ) to 
Table 4. Growing stock of the PF in Sumberejo.

\begin{tabular}{|c|c|c|c|c|c|c|}
\hline \multirow[b]{2}{*}{$\begin{array}{c}\text { Diameter } \\
\text { classes }\end{array}$} & \multicolumn{3}{|c|}{ Monoculture (teak, $\mathrm{n}=10$ plots) } & \multicolumn{3}{|c|}{ Agroforestry (teak, $n=15$ plots) } \\
\hline & $\begin{array}{l}\text { Average } \\
\text { diameter } \\
\text { (cm) }\end{array}$ & $\begin{array}{c}\text { Estimated } \\
\text { Height }^{*} \\
\text { (m) }\end{array}$ & $\begin{array}{c}\text { Number } \\
\text { of stands } \\
\text { per } \\
\text { hectare }\end{array}$ & $\begin{array}{c}\text { Average } \\
\text { diameter } \\
\text { (cm) }\end{array}$ & $\begin{array}{c}\text { Estimated } \\
\text { Height }^{*)} \\
\text { (m) }\end{array}$ & $\begin{array}{c}\text { Number of } \\
\text { stands } \\
\text { per } \\
\text { hectare }\end{array}$ \\
\hline $5-9$ & 7.29 & 3 & 1,240 & 7.57 & 3 & 670 \\
\hline $10-14$ & 12.69 & 4 & 510 & 13.15 & 4 & 210 \\
\hline $15-19$ & 17.63 & 5 & 150 & 17.84 & 5 & 40 \\
\hline$>20$ & 22.05 & 6 & 90 & 22.42 & 6 & 20 \\
\hline Total & & & 1,990 & & & 940 \\
\hline
\end{tabular}

Source: Field survey in 2000.

Notes: Forest inventory was conducted on 25 plots of several farmers' PF which each plot size is $20 \mathrm{~m} \times 10 \mathrm{~m}$ or 0.02 ha for each plot.*) The estimated height is the height of main stems.

Table 5. The income of farmer's households in Sumberejo from various sources during a year in 2000.

\begin{tabular}{crrrrrrr}
\hline $\begin{array}{c}\text { Land } \\
\text { ownership } \\
\text { level }\end{array}$ & $\begin{array}{c}\text { Private } \\
\text { forest }\end{array}$ & $\begin{array}{c}\text { Rice } \\
\text { farming }\end{array}$ & $\begin{array}{c}\text { Dry-land } \\
\text { farming }\end{array}$ & Livestock & $\begin{array}{c}\text { Other } \\
\text { sources }\end{array}$ & Total & $\begin{array}{c}\text { The PF } \\
\text { contribution }\end{array}$ \\
\hline I (<1 ha) & 675,000 & 355,000 & 788,150 & 100,000 & 550,000 & $2,468,150$ & 27.35 \\
II (1-2 ha) & 714,300 & 519,300 & $1,056,050$ & 542,800 & 932,850 & $3,765,300$ & 18.97 \\
III (> 2 ha) & $1,032,900$ & 328,600 & $1,103,100$ & 754,900 & $1,879,300$ & $5,098,800$ & 20.26 \\
\hline Average & 807,400 & 400,967 & 982,433 & 465,900 & $1,120,717$ & $3,777,417$ & 21.37 \\
\hline$\%$ & 21.37 & 10.61 & 26.01 & 12.33 & 29.67 & 100 & \\
\hline
\end{tabular}

Source: Questionnaire results in 2000.

Notes: 1) "Dry land farming" include maize, cassava, peanut, and banana 2) "Other Sources" include off-farm activities in urban area such as wage labourer on building construction, trishaw rider, and petty traders. Rp in Indonesian rupiah (approximately $1 \mathrm{USS}=\operatorname{Rp} 9,000$ )

the farmer's household income, while the PF contributed $21.37 \%$ to the farmer's household income. Other sources of farmer's household income were livestock and off-farm activities. Off-farm activities were commonly conducted in urban area such as wage laborer on building construction, trishaw rider, and petty trader. It is very common when farming season was over, many farmers in Sumberejo and other villages of Wonogiri went to urban areas to work to earn additional income for their livelihood.

The farmer's income is various based on land ownership levels. The farmer's income increases in line with the increasing of land ownership. However this phenomena is inversed if we look to the contribution of the PF toward farmer's income, where the lowest land ownership (level I) has a bigger contribution than the highest land ownership (level III). As a whole, inference from the three strata shows that the farmers obtain contribution from the PF as much as $21.37 \%$. It means that the PF is not a main income source in a farmer's household. Although the PF is not a main income source to serve daily farmer's livelihood, but it is still important for any contingency. According to farmers in this study area, the PF is considered as saving asset which is able to provide big cash for farmers on urgent situations or special purposes such as rebuilding house, wedding party and school fee for their children.

\section{Timber marketing}

As mentioned above, farmers sold selective timber trees to assemblers, wholesalers, or wood processing industries. However, farmers mostly sold timber trees to nearest assemblers who live in the same village, probably because of convenience, kinship or neighborhood relationship. The initiative for transactions between farmers and buyers may come from both parties. The farmers may come to the buyers (assemblers or local wood processing industries) to negotiate over trees on stumpage or buyers may visit farmers to find timber trees. The selling of standing trees has both advantages and disadvantages for farmers. The farmers 
Table 6. Price of teak and mahogany timber on standing trees in Sumberejo.

\begin{tabular}{ccc}
\hline No. & Diameter of tree $(\mathrm{cm})$ & Timber price $(\mathrm{Rp})$ \\
\hline 1 & $10-15$ & $50,000-75,000$ \\
2 & $15-20$ & $75,000-100,000$ \\
3 & $20-30$ & $100,000-150,000$ \\
4 & $30-40$ & $150,000-300,000$ \\
\hline
\end{tabular}

Source: field survey in 2000. Rp in Indonesian rupiah (approximately 1 US\$ = Rp 9,000)

Table 7. Number of wood furniture industries in Wonogiri and neighboring districts.

\begin{tabular}{|c|c|c|c|c|c|c|c|c|}
\hline \multirow[t]{2}{*}{ No. } & \multirow[t]{2}{*}{ District } & \multicolumn{3}{|c|}{ Number of Enterprises } & \multicolumn{3}{|c|}{ Number of workers } & \multirow{2}{*}{$\begin{array}{l}\text { Market } \\
\text { served }\end{array}$} \\
\hline & & Informal & Formal & Total & Informal & Formal & Total & \\
\hline 1. & Wonogiri & 201 & 40 & 241 & 476 & 291 & 767 & $\mathrm{D}$ \\
\hline 2. & Sukoharjo & 69 & 33 & 102 & 235 & 579 & 814 & $\mathrm{D}, \mathrm{E}$ \\
\hline 3. & Surakarta & - & 11 & 11 & - & 93 & 93 & $\mathrm{D}, \mathrm{E}$ \\
\hline 4. & Karang Anyar & 25 & - & 25 & 51 & - & 51 & $\mathrm{D}$ \\
\hline 5. & Klaten & 1,312 & 44 & 1,356 & 3,406 & 300 & 3,706 & $\mathrm{D}, \mathrm{E}$ \\
\hline 7. & Sragen & 1,276 & 60 & 1,336 & 3,584 & 526 & 4,110 & $\mathrm{D}$ \\
\hline & Total & 2,883 & 188 & 3,071 & 7,752 & 1,789 & 9,541 & \\
\hline
\end{tabular}

Source: CEMSED, 2002

Notes: $\mathrm{D}=$ domestic, $\mathrm{E}=$ export

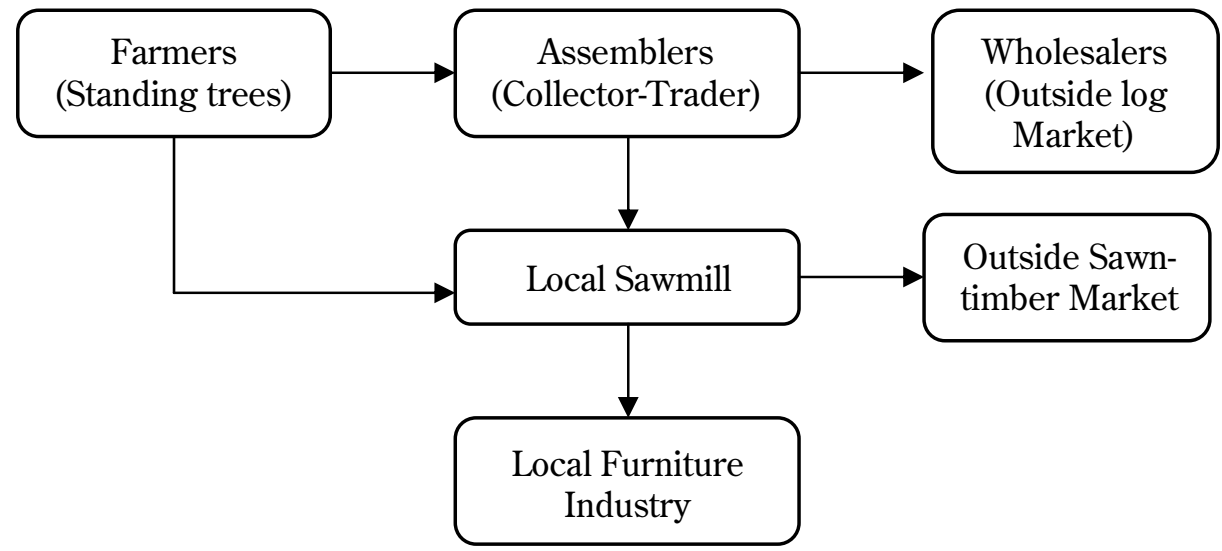

Fig. 2. Distribution/marketing channel of timber in Sumberejo.

Source: Field observation in 2000

do not need to spend extra-cost for harvesting and transportation. However, farmers have no bargaining position in determining price since they need cash during the emergency situation. According to FAO (1996), the wide distribution and long marketing channel are characteristics of business in forestry and agricultural products in the villages. In this system, the farmers get smaller profit margin compared to other actors such as assemblers, wholesalers, and owner of timber processing industry. The price of teak and mahogany timber depends on the diameter class of timber trees. The price also depends on location of the timber trees. It is common that more remote areas have lower price levels because of the higher transportation cost paid by buyers. Therefore, the price which farmers receive varies according to diameter and location of timber trees. Based on information from assemblers, price of teak and mahogany timber on standing trees in Sumberejo as is presented in Table 6.

Wholesalers and wood processing industries from outside village buy timber from local assemblers. They may provide credit to several local assemblers and hold stocks of timber. The assemblers mostly store the timber near their houses, in open field, or alongside the road. The transportation of timber from the rural areas to the 
urban markets is mostly conducted by the assemblers with trucks. The flowchart of distribution or marketing channel for teak and mahogany timber in Sumberejo is shown in Fig. 2.

Teak and mahogany logs are used for construction or furniture materials. There are 8 units of small sawmill and 6 units of small furniture industries in Sumberejo. However, most of the teak and mahogany logs are exported to outside village to fulfill wood industries in surrounding Wonogiri District. Table 7 shows the number of wood furniture industries in Wonogiri and neighboring districts. The remains wood from waste of logging extraction is commonly used by farmers as firewood. Besides fulfilling their own need, that firewood are sold by farmers to small factories such as limestone burning, brick, and tofu processing factory which exist around the village.

\section{Role and contribution of the $P F$ in village economy (1) LQ value of the PF sector}

As is presented in Table 8 , the biggest income of Sumberejo in 1999 came from the food-crops agriculture sector whose contribution was about $85.39 \%$. The second biggest income came from the livestock sector which provided $4.85 \%$ of the total village income. Meanwhile the $\mathrm{PF}$ sector provided contribution of $4.56 \%$. This indicates that the PF is not the main income source for Sumberejo Village. As mentioned above that the contribution of PF toward farmer's household income reaches $21.37 \%$ (Table 5), whereas contribution of PF in the village is only $4.56 \%$ (Table 8 ). This difference shows that the PF provides large contribution to farmer's income, but small contribution to the village economy as a whole. This resulted from more various source of village's income (10 economic sectors) than farmer's household income (5 income sources). Consequently, the income contribution of PF to village economy was less significant than to farmer's household.

To give more complete idea of the role of the PF sector in the village, LQ value was calculated by dividing the income contribution of each sector in Sumberejo Village by the income contribution of those sectors in Batuwarno Sub-district. Table 8 shows that LQ value of the PF sector is 1.397, while the food-crops agriculture sector is 1.338. Because of those sectors have LQ value greater than one and therefore those sectors are convinced as basic sector which has an important role in the village economy of Sumberejo. The LQ values also indicate that those sectors are more important for the economy of Sumberejo Village than Batuwarno Subdistrict.

\section{(2) Analysis of income surplus from the PF}

Theory of economic base states the sector which has $\mathrm{LQ}$ value greater than one means that sector is able to fulfill the needs of inside community, and export its excess production to outside. By selling the surplus of product, that sector gets income from outside and then create surplus of income for local economy. From that standpoint we can say that a basic sector will create positive or surplus of income, while non-basic sector will create negative or deficit of income to local economy. To

Table 8. LQ values of various sectors of economy in Sumberejo in 1999.

\begin{tabular}{|c|c|c|c|c|c|c|}
\hline $\begin{array}{l}\text { Sectors of } \\
\text { economy }\end{array}$ & $\begin{array}{l}{ }^{*)} \text { Income of } \\
\text { Vumberejo } \\
\text { Village } \\
(\operatorname{Rp} x 1,000)\end{array}$ & $\begin{array}{l}\text { Contribution } \\
\text { to total } \\
\text { village } \\
\text { income } \\
(\%)\end{array}$ & $\begin{array}{c}{ }^{*)} \text { Income of } \\
\text { Batuwarno } \\
\text { Sub-district } \\
\text { (Rp x } 1 \text { million) }\end{array}$ & $\begin{array}{l}\text { Contribution } \\
\text { to total } \\
\text { sub-district } \\
\text { income } \\
(\%)\end{array}$ & $\begin{array}{c}\text { Value of } \\
\text { LQ }\end{array}$ & $\begin{array}{c}\text { Basic/ } \\
\text { Non basic } \\
\text { sector }\end{array}$ \\
\hline Food-crops agriculture & $3,153,671$ & 85.39 & $7,862,070$ & 63.83 & 1.338 & Basic \\
\hline Livestock & 178,956 & 4.85 & $2,661,927$ & 21.61 & 0.224 & Non basic \\
\hline Fishery & 552 & 0.01 & 5,962 & 0.05 & 0.309 & Non basic \\
\hline Plantation & 5,678 & 0.15 & 181,106 & 1.47 & 0.105 & Non basic \\
\hline Private forest & 168,430 & 4.56 & 402,182 & 3.27 & 1.397 & Basic \\
\hline Other forest product & 12,788 & 0.35 & 128,528 & 1.04 & 0.332 & Non basic \\
\hline Mining & 39,467 & 1.07 & 302,353 & 2.45 & 0.435 & Non basic \\
\hline Small industry & 5,062 & 0.14 & 71,920 & 0.58 & 0.235 & Non basic \\
\hline Tranportation & 5,710 & 0.15 & 147,460 & 1.2 & 0.115 & Non basic \\
\hline Services & 122,898 & 3.33 & 553,674 & 4.5 & 0.740 & Non basic \\
\hline Total & $3,693,212$ & & $12,317,181$ & & & \\
\hline
\end{tabular}

Source: *) Wonogiri District Statistic Office, 2000. Rp in Indonesian rupiah (approximately 1 US\$ = Rp 9,000) 
analyze whether each sector create surplus or deficit of income to village economy of Sumberejo, surplus index was calculated by comparing the income contribution of each sector in Sumberejo to the income contribution of those sectors in Batuwarno. Table 9 shows that the foodcrops agriculture and the PF sectors have positive sign of surplus index. By multiplying the surplus index with the original income of those sectors in the village, we found the income surplus of the food-crops agriculture and the PF sectors are Rp 679,931,467 and Rp 2,172,747, respectively. Meanwhile the other sectors have negative sign of surplus index which create deficit income to village economy of Sumberejo. We sum-up here that the food-crops agriculture and the PF sector are basic sectors which created income surplus to village economy of Sumberejo.

\section{(3) Analysis of $M_{e}$ of the PF as basic sector on village economy}

Basic or export sectors which create income surplus to local economy will grow up local economy activities because the income from those sectors will be used to purchase insufficient products of non-basic or local sectors. The impact of basic sector to local economy can be calculated using multiplier effect analysis. Table 10 shows the coefficient of multiplier effect $\left(\mathrm{M}_{\mathrm{e}}\right)$ for the PF and food-crops agriculture sectors which were calculated by dividing the total income of Sumberejo by the income of those basic sectors. The calculation found out that the PF sector has $\mathrm{M}_{\mathrm{e}}$ of 21.927, whereas the food-crops agriculture sector has $\mathrm{M}_{\mathrm{e}}$ of 1.171. Because of the $\mathrm{Me}_{\mathrm{e}}$ value of PF bigger than food-crops agriculture sector, then $\mathrm{PF}$ is proved as "prime mover role" sector in economy of Sumberejo. This result can be used to predict the effect of the PF sector to stimulate other sectors economy in this village. For example, if the $\mathrm{Me}_{\mathrm{e}}$ of the PF sector is 21.927 , it can be expected that by spending Rp 1 of the $\mathrm{PF}$ income will stimulate income of non-basic sectors by Rp 21.927. However, according to Hoover (1971), Isard (1972), and Isserman (1977), such interpretation could not be strictly applied because other influencing factors, such as inflation rate, saving rate of community, etc. should be considered. The $\mathrm{M}_{\mathrm{e}}$ value should be viewed as a general idea that the basic sector can develop income of other sectors (non-basic sectors), which finally increase total income in the village.

Table 9. Income surplus for each sector of economy in Sumberejo in 1999.

\begin{tabular}{|c|c|c|c|}
\hline Sectors of economy & Surplus Index ${ }^{1)}$ & $\begin{array}{l}{ }^{*)} \text { Income } \\
(\mathrm{Rp}) \times 1,000\end{array}$ & $\begin{array}{l}\text { Surplus of income } \\
\text { (Rp) }\end{array}$ \\
\hline Food-crops agriculture & 0.2156 & $3,153,671$ & $679,931,467$ \\
\hline Livestock & -0.1670 & 178,956 & $-30,003,679$ \\
\hline Fishery & -0.0004 & 552 & -185 \\
\hline Plantation & -0.0132 & 5,678 & $-74,757$ \\
\hline Private forest & 0.0129 & 168,430 & $2,172,747$ \\
\hline Other forest product & -0.0069 & 12,788 & $-89,161$ \\
\hline Mining & -0.0138 & 39,467 & $-547,048$ \\
\hline Small industry & -0.0044 & 5,062 & $-22,619$ \\
\hline Tranportation & -0.0106 & 5,710 & $-60,533$ \\
\hline Services & -0.0117 & 122,898 & $-1,434,789$ \\
\hline
\end{tabular}

Table 10. Calculation of multiplier effect coefficient $\left(M_{e}\right)$ of basic sectors in Sumberejo.

\begin{tabular}{cccc}
\hline *Basic economic sector & $\begin{array}{c}{ }^{*} \text { Total income of Sumberejo } \\
\text { from all economic sectors (Rp) }\end{array}$ & $\begin{array}{c}{ }^{*} \text { Income from } \\
\text { a basic sector } \\
(\mathrm{Rp})\end{array}$ & $\begin{array}{c}\text { Coefficient of } \\
\text { multiplier effect } \\
\left(\mathrm{M}_{\mathrm{e}}\right)\end{array}$ \\
\hline Private Forest & $3,693,212,000$ & $168,430,000$ & 21.927 \\
Food-crops agriculture & $3,693,212,000$ & $3,153,671,000$ & 1.171 \\
\hline
\end{tabular}

Source: ${ }^{*}$ Wonogiri District Statistic Office, 2000 


\section{DISCUSSION}

A large area in Sumberejo is characterized by stony, steep, and poor soil with a shortage of rainfall. Therefore, the land in this area is less productive and profitable for intensive agricultural crops. Except trees, many farmers have not enough alternatives to grow plant species. To respond to the constraints concerning land conditions as well as a high demand for timber in surrounding areas, farmers plant valuable trees, mainly teak and mahogany. As result, Sumberejo has PF on a large area.

Similar with previous study of PF in Wonosobo and Cianjur Districts (Ichwandi et al. 2005), the PF management applied by farmers in Sumberejo is quite simple without practicing a proper silvicultural techniques. Planting materials are mainly from natural regeneration, while land preparation, planting and maintaining the trees are practiced by farmers on their own habit. Marketing of timber is conducted on standing trees (stumpage) which were chosen by buyers for cutting. Nevertheless, some differences were also found in this study concerning species and planting system applied by farmers. Farmers in Sumberejo prefer to plant teak and mahogany species because of high demand for these timber trees and proper with their land condition. Besides agroforestry system, farmers in Sumberejo applied monoculture and polyculture systems on their PF.

Based on forest inventory, the growing stock per hectare of PF in Sumberejo was higher than Wonosobo and Cianjur. This indicated that farmers in Sumberejo planted trees more intensive than Wonosobo and Cianjur. It was not so surprising because the lands in Sumberejo are less fertile and less suitable for agriculture crops than Wonosobo and Cianjur. Although farmers in Sumberejo plant trees more intensive than Wonosobo and Cianjur, but the contribution of PF to farmer's household income is relatively similar. The PF has not contributed a big portion to the total household income. Based on this study, the PF contributed as much as $21.37 \%$ to farmer's household income. It is not so high compared to other income sources. Timber as forest product is characterized by a long period of producing process. Consequently, it also brings income after a long period of time. Therefore, PF was not suitable as the main income source for daily life, but PF had an important role in the farmer's household as a saving asset. Farmers considered that $\mathrm{PF}$ is able to provide big cash for them on urgent situation or special purposes such as rebuilding house, school fee for their children, etc. As Chambers \& Leach
(1987) mentioned, that poor people often planted trees to meet contingencies and as a part of deliberate longterm strategies for saving and security. Timber trees have functioned as saving asset because of several advantage characteristics i.e. safety asset with a high durability without loss of value, even grow or increase in time, and can be easily transformed to a cash asset. So, this study supports the previous study of PF conducted by Ichwandi el al. (2005) in Wonosobo and Cianjur concerning the role played by PF on farmer's household. This study did not analyze financial aspect to evaluate prospective of the PF as farm-business investment. However, with a consideration that cutting cycle of teak and mahogany are longer than albizia, we can predict the rate of investment return of PF in Sumberejo is smaller than Wonosobo and Cianjur.

Economic prosperity is based on the ability of a community to export good and/or service beyond its borders, bringing money into the community. The sector that is export oriented is called as a basic or leading sector which will drive the area's economy, supporting all the other sectors that serve local demand. To know whether the PF is a basic sector or not and what the role of that sector is in village economy of Sumberejo, economic base technique was applied. The purpose is to help planners, analysts, and interest groups to estimate the total economic effect of the PF on local economy and to aid in understanding how that sector related to other sectors of the local economy. This information can be used by planners to conduct better economy strategies. Economic base technique has been applied by many researchers in many sectors and aspects of regional economy. Therefore, we tried to apply that technique to analyze the role played by the PF on local economy. We realized that this study is quite new and it was not supported by perfect statistical data. With limitedavailable data, the study employed three analytical tools (LQ, $\mathrm{S}_{\mathrm{y}}$, and $\mathrm{M}_{\mathrm{e}}$ ).

The result of this study proved that the PF and foodcrops agriculture sectors in Sumberejo have LQ bigger than one. This indicated that those sectors are a basic sector. This implies that those sectors were self-sufficient, producing more than what were needed for local use and selling the surplus outside the village. By selling the surplus of product, those sectors gave income to the village and created surplus of income for village economy. Other sectors such as livestock, mining, services, etc. also created income and contributed to village economy, but they have deficit (negative) of income. This indicated that those sectors produce products less than what were 
needed for local use and buying the deficit from outside using the income coming from the basis sector. The $\mathrm{PF}$ and the food-crops agriculture sectors contribute to economic growth on by stimulating additional local economy activity as money (Rp) generated from those products export are used for purchases within the village. Further analysis found that the PF sector has $M_{e}$ value bigger than the food-crops agriculture. This realized that multiplier effect of the PF is bigger than the foodcrops agriculture sector. The PF in Sumberejo was able to become a basic sector which has strong impact to the village economy because of some following factors; (a) suitability of woody crops to grow in marginal land, where only woody species are more suitable to grow in marginal-land, and provide economic benefit to farmers, (b) growing trees is becoming more attractive to farmers, not only because they can be sold but also they are less labour demand and can be produced with little capital investment (trees species such as teak and mahogany are easy to grow since they generate naturally), (c) growing trees does not need input from import (outside village), so the leakage out of income from PF sector is minimum. Due to lack of statistical data both in the village and subdistrict level concerning employment on each sector, disposable income and saving level of community, etc. this study could not analyze completely the role played by PF on local economy. This study, however, concluded that PF in Sumberejo is "prime mover role" sector and therefore it can be promote as "engine" for economic development in this village. This information gives us some idea on how to strengthen local economy through developing the PF sector.

A large amount of timber produced by $\mathrm{PF}$ in Sumberejo created market for timber in this village and its surrounding areas. It is giving chance to improve sectors related the PF such as wood trading and wood processing industries. Development of wood processing industries in this village can improve value added of timber, create new employment opportunities, and increase demand for supporting-wood industries. To speed up economic growth in the area on which timber as comparative advantages, development of downstream wood-industry is appropriate strategy to be proposed. The reason is that industry commonly has forward and backward linkages to other sectors.

A large area of PF in Sumberejo led this village as one of seed producer of teak and mahogany in Java. As reported by Roshetko et al. (2004), a large area of PF in many villages in Wonogiri District leads this district to the main source of tree seed in Indonesia. Traditionally, local peoples who collect seed depend on delivery order from outside seed traders. Local seed collectors also have limited capacity to collect good quality of seed and therefore they are not able to sale it on a better price. So, train local people on seed collecting and marketing is also another chance to encourage the PF sector in local economy.

Timber market in this village was characterized by a long distribution channel, which involved many actors i.e. assemblers, wholesalers, and wood processors. Farmers who sell timber on standing trees (stumpage) and commonly under urgent situation have lower position compared to the buyers in determining timber price. The problem is how to help farmers to improve their bargaining position on timber market. To improve bargaining position, farmers in village normally require organization such as cooperative or farm association (FAO, 1996). Through these organizations, decisions of common interest can be reached and acted upon. By working together, members of an organization can gain bargaining power with traders and middleman, so that they maximize their profit. This organization can also play an important role in training its members in various aspects of production and marketing. We know that farmers in Sumberejo have farmer group called Gondangrejo. However, this organization is still not well organized and ineffective to handle marketing problem. In recent years, collaboration between many institutions, such as local government, NGO, researchers, who concern with farmers' condition has been declared. Some action programs have been initiated to strengthen farmer's organization in this village. In October 2004, forest farmers' community in Sumberejo village got "ecolabel" certificate from LEI (The Indonesian Ecolabelling Institute) to appreciate farmers on managing their PF on sustainable manner. That certificate is expected can help farmers to get better position on determining timber price. Better price which farmers get will stimulate them to expand their $\mathrm{PF}$, and then give stimulus to other sectors on local economy.

\section{REFERENCES}

Anonymous. 1996. Stabilization and optimization of forest resources in Java Island (in Indonesian), Final report; Collaboration Project between Faculty of Forestry, Bogor Agricultural University and Perum Perhutani. 123 pp.

BPS. 1993. Census of Agriculture in 1993 (in Indonesian). Biro Pusat Statistik, Jakarta. 
CEMSED. 2002. Value chain analysis of furniture clusters in Central Java. Report on a survey prepared for the ILO, Salatiga.

Chambers, R. \& Leach, M. 1987 Tree to meet contingencies: Saving and security for rural poor. Social Forestry Network, Odi, Network paper 5a. 29 pp.

FAO. 1996. Marketing in forestry and agroforestry by rural people. Forestry Department, FAO, Bangkok. $36 \mathrm{pp}$.

Hoover, E.M. 1971. An Introduction to Regional Economic. Alfred A. Knopf Inc., University of Pittsburgh, New York. 120 pp.

Ichwandi, I., Shinohara, T., \& Nakama, Y. 2005. Characteristics of private forest management in Java, Indonesia; Two case studies. Journal of Forest Economic, 51: 1-12.

Isard, W. 1972. Methods of Regional Analysis an Introduction to Regional Science. Massachusetts Institute of Technology, London. $88 \mathrm{pp.}$

Isserman, A. 1977. The location approach to estimating regional economic impacts. AIP Journal, 240: 33-34.

Klosterman, R.E. 1990. Community and Analysis Planning Technique. Rowmand and Litllefield Publishers, Inc. Savage, Maryland.

Ministry of Forestry. 2003. Statistics of forestry 2002 (in Indonesian), Departemen Kehutanan, Jakarta

Nair, P.K.R. 1993. An Introduction to Agroforestry. Kluwer Academic Publishers, Dordrecht, The Netherlands.

Nemoto, A. 2002. Farm tree planting and the wood industry in Indonesia: a study of falcataria plantations and the falcataria product market in Java. Policy Trend Report, 2002: 42-51.

Robert, S. \& Dubois, O. 1996. The role of social/farm forestry schemes in supplying fiber to the pulp and paper industry. Report for IIED Sustainable Paper Cycle Study, IIED, London, UK. 33 pp.

Roshetko, J.M., Mulawarman, D. \& Iriantono. 2004. Tree seed procurement-diffusion pathways in Wonogiri and Ponorogo, Java: Indonesia's main source of tree seed. ICRAF Southeast Asia. Working Paper No 2004-1. 14 pp.

Soerjohadikoesumo, J. 1980. Wood supply in Java (in Indonesian). Perum Perhutani, Jakarta. 42 pp.

Simon, H. 1999. Cooperative forest management with local peoples: Theory and application on teak forest in Java (in Indonesian). BIGRAF Publishing, Yogyakarta.
Wiersum, K.F. 1982. Tree gardening and taungya in Java: Examples of agroforestry techniques in the humid tropics. Agroforestry Systems, 1: 53-70.

Wonogiri District Statistic Office. 2000. Batuwarno subdistrict in figures 2000 (in Indonesia). Wonogiri, Central Java. 252 pp.

Received 24 ${ }^{\text {th }}$ Oct. 2005

Accepted $1^{\text {st }}$ May 2006 